\title{
Toplum Tipleri ve Yalnızlık Halleri
}

\author{
DOI: 10.26466/opus.519612 \\ *
}

Ejder Ulutaș* ${ }^{*}$ Ahmet Gökçen ${ }^{* *}$

\author{
* Dr. Öğr. Üyesi, Muş Alparslan Üniversitesi Sosyoloji Bölümü Muş/Türkiye \\ E-Posta: e.ulutas@alparslan.edu.tr \\ ORCID: 0000-0002-3599-6181 \\ ** Dr. Öğr. Üyesi, Muş Alparslan Üniversitesi Sosyoloji Bölümü Muş /Türkiye \\ E-Posta: ahmetgokcen 47@hotmail.com \\ ORCID: $\underline{0000-0002-8150-1880}$
}

\section{Öz}

Toplum tipleri, hemen her sosyal bilimci tarafından çeşitli toplumsal dinamikler dikkate alınarak farklı farklı kavramsallaştırmalara tabi tutulmuştur. Bu çoklu tanımlamalar, sosyal bilim açısından önemli zenginlikleri barındırmakla beraber bir takım belirsizlikleri de beraberinde getirmektedir. Yalnuzlik, sadece bu yeni toplum tiplerinde görülen bir olgu değildir. Fakat yalnızlı̆̆ı bu denli popüler olması, yeni toplum tiplerine özgüdür. Yalnızlk, -bir psikolojik yaklaşımdan öte-sosyal bilim teorisyenlerinin sıklikla bahsettiği bir olgudur. Yeni toplum tiplerinin temel özelliklerinden biri olan bireyselleşme olgusu, yalnızlığın önemli bir etkeni olarak kodlanmaktadır. Yalnızlık olgusunun mekânsal, ilişkisel, dini, ekonomik, kültürel, siyasal, sımıfsal vs. birçok sosyolojik boyutundan bahsedilebilir. Bu çalışmada, yalnızlık olgusu çerçevesinde yürütülen psikolojik tanımlamalar ve tartışmalar bir tarafa bırakılarak yalnızlık hallerinin toplum tiplerinde nereye denk düştüğ̈̈ çeşitli kavramlar, sosyal olgular ile kurumlar, teori/teorisyenler ve gündelik yaşam pratiklerine değinilerek açıklanmaya çalışlacaktır. Çalışmada önemli sosyal bilim teorisyenlerinin kavramsallaştırdığı toplum tiplerindeki yalnızlık olgusunun sosyolojik boyutlar irdelenmektedir. Dolayısıyla çalışma, sosyal bilimcilerin yeni toplum tiplerine yaklaşımları ve yalnızlık tanımlamaları üzerine odaklanmaktadır. Bu bağlamda, bir çeşit "kavramsal yalnızlık haritası" çıkarmak hedeflenmektedir.

Anahtar Kelimeler: Yalnızlık, Toplum Tipleri, Bireyselleşme, Sosyal Teori 


\title{
Society Types and States of Loneliness
}

\begin{abstract}
Society types have been conceptualized by almost every social scientist being considered according to various social dynamics. These multiple definitions have important richness in terms of social science yet bring with them some uncertainties. Loneliness is not a phenomenon seen just in the new society types. However, its being that popular is specific to the new society types. Loneliness is a phenomenon frequently mentioned by sociology theorists rather than a psychological approach. The individualization phenomenon which is one of the basic features of the new society types, is coded as an important factor of loneliness. Loneliness can be said to have many dimensions like spatial, relational, religious, economic, cultural, political, class and etc. In this study, the psychological definitions and debates related to the loneliness phenomenon are put aside and where the states of loneliness coincide in the types of society is discussed through various concepts, social phenomena and institutions, theory/theorists and daily life practices. In the study, the sociological aspects of the loneliness phenomenon in the societies conceptualized by important social science theorists are analyzed. Thus, it focuses on sociologists' approaches to the new society types and their definitions of loneliness. In this context, it is aimed to create kind of a "conceptual loneliness map".
\end{abstract}

Keywords: Loneliness, Society Types, Individualization, Social Theory 


\section{Giriş}

Modern dönemde toplumu açılamak için girişilen her uğraş ya yeni teoriler üretmekte ya da var olan bir takım teorilere yaslanmaktadır. Klasik teorisyenler, Batı kartezyenizminin etkisiyle, toplumu kavram ikilileri üzerinden açıklama ve anlama yoluna gitmişlerdir. Geleneksel ile modern dünya arasındaki ayrımda dikkati çeken temel nokta, söz konusu ayrımın gündelik hayat pratikleri üzerinden kurgulanmasıdır. Geleneksel ve modern olanın ne olduğu sorularına verilen cevaplar genellikle gündelik yaşamdaki ilişkilerin ne şekilde tezahür ettiğini de bir açıdan ele vermektedir. Geleneksel dünyaya yapılan atıfta ilişkilerin yüz yüze, yakın ve duygusal olduğundan dem vurulurken, modern dönem, ikincil yahut resmi ilişkilere atıfla tanımlanmaktadır. Sosyoloji tarihinin klasik isimleri olan Emile Durkheim, Karl Marx, Max Weber, Ferdinand Tönnies, Georg Simmel, David Riesman gibi düşünürler, dönemin makro açıklamaları çerçevesince toplumu anlama ve açılama yoluna gitmişlerdir.

Özellikle bir bilim olarak ortaya çalıştığı dönemlerde sosyolojinin, evreni açıklamayı hedeflemiş fen bilimlerinden geri kalmaması için makro teorilere yaslanması gerektiği düşüncesi hâkimdir Pozitivist paradigmayla karılmış bir toplum okumasında bireyin kim olduğu sorusu tali bir soru olarak kalmıştır. Simmel dışında, hassaten toplum içerisindeki birey pek kayda değer görülmemiş ve incelenmemiştir. Klasik isimlerin önemli bir kısmı, toplumu anlamak yerine onu total bir açılama nesnesi olarak görmüştür. Durkheim'in mekanik ve organik dayanışması, Marx'ın tarihsel materyalizmi, Weber' in meşruiyet tipleri, Tönnies'in topluluk ve toplumu, Riesman'ın gelenek yönelimli/içe ve dışa dönük toplum tipolojileri, makro ölçekli toplumsal dönem ve yapıları incelemeye azmederken bireyi önemli ölçüde teğet geçmiştir. Büyük ölçekli teorilerde çoğunlukla birey, tarihsel çatışma, değişim ve kırılmaların açıklamasında kullanılan bir ayrıntı gibi durmaktadır. Söz konusu teori ve bakış açıları, toplumsal süreci okumanın farklı paradigmalarına işaret etmektedir. Her teori toplumu kendince yorumlamış, sorunların tespiti ve hallinin nasıl olacağına dair bir dizi reçete ileri sürmüştür.

Toplumu açiklama biçimlerinin hâkim paradigmanın etkisi altındaki karar vermelerini bir nebze anlamak mümkündür. Ancak toplumsal bir varlık olarak bireyin sosyolojik analizlerde pek dikkate alınmaması uzun 
bir süre devam etmemiştir. Nitekim özellikle ikinci dünya savaşı sonrası dönemde toplumu açıklamaktan ziyade onu anlamanın daha önemli olduğu genel kabul görmüştür. Sosyal bilimler paradigmasının "anlama" lehine direksiyon kırması, araştırmacıların, makro ölçekli açıklamaların kenarda bıraktığı bireye eğilmelerini beraberinde getirmiştir. Toplumsal hayatın ilişkisel boyutları üzerine yaklaşımlar ortaya konarak, gündelik yaşam içerisindeki bireyin anlam dünyasını çözümleme yoluna gidilmiştir. Sosyal psikolojik bir çeşniyle karılan sosyolojik teoriler, toplumun mikro ölçekli ilişkilerine dokunmaya çalışmışlardır. Kıyıda köşede kalmış hayatların izleri sürülerek, sosyal bilimlerin yeni paradigmasına veri depolanmaya çalışılmıştır. Netice itibariyle modern dönemde öylesine değinilerek açıklanan birey, yeni dönemde (post-modern de denebilir) başrole geçmiştir. Önceki dönemde figürasyon görevi gören ve ince ayrıntılarına inilmeyen birey, başrol olunca etraflı analizlerin odağı haline gelmiştir. Birey ne demektir? Kimdir? Ne yer ve içer? Nasıl yaşar? Nasıl anlam üretir? Varlık sebebi nedir? Toplumsal yaşamda nerede durur? gibi arttırılabilecek soruların muhatabı haline gelmiştir.

Daha önce eşine benzerine rastlanılmayan yeni toplum tanımlamalarıyla karşı karşıya olduğumuzu ifade etmek gerekmektedir. Toplumu konu edinen özelde sosyoloji genelde sosyal bilim teorisyenleri, yeni toplumsal yapıyı açıklamak adına çeşitli korelasyonlar, kavramsal tasarımlar, imgesel anlatılar, ilişki ağları ve temel varsaydıkları dinamiklerden hareket ederek tezlerini öne sürmüşlerdir. Yeni toplum tipinin bu şekilde ifşası, bilim adına önemli bir zenginliğin göstergesidir denebilir. Zira daha önce basit veya bazı ikili sinıflandırmalar üzerine oturtulan toplum tipleri artık çoklu tanımlamalarla irdelenmektedir. Bu zenginliğin bilim adına olumlu yanı bir tarafa, toplum için bu tezlerin ürettiği belirli bazı belirsizlikler de söz konusudur. Yeni toplumun belirsizliği, teorisyenlerin teorik çerçevesini aşar niteliktedir. Beck (2011), bu belirsizliği risk ve güvensizlik üzerine inşa etse de onun bu tezi, varış noktasının belirli olmadığ bir toplumu anlatagelmektedir ${ }^{1}$. Belirsizlikler üzerine yoğunlaşan bir diğer sosyal bilimci Eagleton, postmodern olarak adlandırılan yeni dönemin birçok müphemliği içerisinde barındırdığına dair örnekler vermektedir (2015, s.38-68). Çok bilinen bir diğer teoride Castells (2013),

\footnotetext{
${ }^{1}$ Risk toplumu üzerine son dönemde yapılan bir çalışma için bkz. Günerigök, 2018
} 
"Enformasyon çağı" olarak tanımladığı günümüz dünyasının toplumsal yapısını "A $\breve{g}$ Toplumu" kavramıyla biçimlendirmiştir. Vattimo, Şeffaf Toplum'unda Castells'e paralel bir biçimde, yaşadığımız toplumun bir kitle iletişim araçları toplumu olduğunu belirtmiştir (2012, s.9). Yeni toplum tipini "tüketim" kavramını merkeze alarak açıklayan Baudrillard (2016), "Homo Economicus" olarak tanımladığı insan tipini bu toplum tipinin temel aktörü olarak göstermiştir. Debord bu tüketim durumunu öte bir alana taşıyarak "gösteri" üzerine yoğunlaşmıştır. Ona göre "gösteri paranın öteki yüzüdür" (2012, s.54).

Debord gösterinin sadece ekonomik değil siyasal alanda da ön plana çıktığını savunmaktadır. Gösteri/ş için tüketim Debord'dan önce Veblen'in Aylak Sınıfın Teorisi'ni (2017) oluştururken kullandığı önemli kavramsallaştırmalardan biridir. Veblen'in çağdaşı olan Sombart (1998), toplumda gösterişle paralel bir kavram olan "lüks"ün önemi üzerine yoğunlaşmış ve kavramı kapitalizmin temeline oturtmuştur. Tüketim üzerine yoğunlaşan daha çağdaş bir teorisyen olan Ritzer (2016), tüketim araçlarının çeşitliliği ve tüketim hızının artmasını dünyayı yeniden büyülemek olarak imgeleştirmektedir. Yeni topluma duygu sosyolojisi çerçevesinden bakan Mestrovic (1997), modernist anlatıların artık etkisini yitirdiğini, kutsalın ve kolektif bilincin ortadan kaybolduğunu, ölümün bile büyük anlam dönüşümüne uğradığını belirtmektedir. Byung-Chul Han'ın işi abartıp -fakat haklılık payı yüksek olmakla birlikte- yeni toplum biçimini Yorgunluk Toplumu (2017a) olarak kavramsallaştırmasının ardından Şeffaflık Toplumu, Olumluluk Toplumu, Teşhircilik Toplumu, Apaçıklık Toplumu, Porno Toplumu, İvme Toplumu, Teklifsizlik Toplumu, Enformasyon Toplumu, İfşa Toplumu ve Kontrol Toplumu kavramsallaştırmalarını kullanması (2017b) daha önce belirttiğimiz çoklu tanımlamalara önemli bir örnek teşkil etmektedir.

Yeni toplum tipini açıklamaya yönelik sayılan -ve dahi sayılamayanteorilerin şüphesiz üzerinde uzlaştığı ve bu yeni toplum tipini oluşturan temel dinamikler söz konusudur. Çeşitli ideolojik yaklaşımlardan arındırılmış bir biçimde küreselleşme, sekülerleşme ve bireyselleşme kavramları/süreçleri bu dinamiklerin başında gelmektedir. Sürecin küreselleşme ve sekülerleşme boyutunu başka çalışmalara havale edip, burada üzerinde odaklanacağımız "yalnızlık" olgusunu bireyselleşme üzerine inşa etmeye çalışacağız. 


\section{İnsan ve Toplum}

İnsanın toplumsal bir varlık oluşu üzerine ciddi bir literatürün varlığı söz konusudur. İnsanın düşünen, konuşan, alet yapan, oyun oynayan vb. özelliklerine atıfla yapılan açıklamalar en temelde onun toplumsal bir varlık olmasına göndermede bulunmaktadır. İnsanın diğer canlılardan farklı olarak çevresine yorum katabilme özelliği, onu başkaları ile bir arada yaşamaya sevk eden önemli saiklerden biridir. Hayatı anlama ve yorumlama sürecinde insan yalnız değildir. Onun gibi düşünen, eyleyen insanlara ihtiyaç duymaktadır. Kimi zaman beraber kimi zaman birbiriyle ve hayatla yaka paça sürdürülen ilişkiler, gündelik yaşamın akışında yoluna devam etmektedir. İnsan sadece düşünen, anlam veren bir varlık değildir.

Mengüşoğlu'nun (2015) da ifade ettiği üzere insan; tavır takınan, önceden gören ve belirleyen, isteyen, özgür hareketleri olan, tarihsel, kendisini bir şeye veren, seven, çalışan, eğiten/eğitilen, devlet kuran, inanan, sanatın ve tekniğin yaratıcısı olan, konuşan, biyo-psişik yapıya sahip olan bir varlıktır.

Mengüşoğlu'na göre (2015, s.20-23) akış içinde bulunan insan hayatta tek başına değildir. İnsan ister istemez başka insanlarla bir arada yaşamak durumundadır². Çünkü başkaları da kendisi gibi yapıp-eden varlıklardır. İnsanın yapıp-etmeleri ile hayatın birlikte getirdiği durumlar, olaylar karşısında ilgisiz kalması düşünülemez; çünkü insanların yapıp-etmeleri ya birbirine karşıdır yahut birbirini tamamlamaktadır. Ayrıca insan disharmonik bir varlık-yapısına sahiptir; insanın bu varlık-yapısı, hem iyinin, hem kötünün, hem haklılığın, hem haksızlığın, hem melek olmanın hem de şeytan olmanın birbirine karşıt "çekirdeklerini" içinde taşımaktadır. İnsan bu disharmonik yapısını dizginlemek için devlet kurmak zorunda kalmış ve bu kurumu geliştirme yoluna gitmiştir. Aristoteles de bütün toplumların birer anlam fabrikaları olduğu kaydını düşmektedir. Bir Polis'in dışında kalan tek başına bir varlığın ancak bir melek ya da bir canavar olabileceğini dile getiren Aristoteles (Bauman, 2015, s.11), insanın toplum içerisinde anlam kazanabildiğini hatırlatmaktadır. Ayrıca

\footnotetext{
${ }^{2}$ Ayrica bkz. ibn-i Haldun, 2013.
} 
Aristoteles' in toplumun doğası üzerine düşünceleri, insani birlik veya ortaklık biçimlerinin analizi üzerinden, şehir devletinde yurttaşlar arasında gerçekleşen ortaklık biçimi olan devlet kavramının analizine ulaşmaktadır. Söz konusu analizdeki birlik, ortaklık ve toplum kavramları, devlet terimi altında toplanmıştır (Sayer ve Frisby, 2017, s.16). Toplum ve devlet kavramlarının yakın menzilli kullanımı, toplum kavramı üzerinde ciddi bir ittifakı uzun bir süre akim bırakmıştır. Dolayısıyla toplum kavramının neliği meselesi, insanın da neredeliğine cevabını bünyesinde saklı tutmaktadır.

Becker (2016) toplum kavramına temsiller üzerinde yaklaşmayı salık vermektedir. Toplum hakkında bir şeyler ifade etmenin, onu belli temsillere göndermede bulunularak gerçekleşebileceğini dile getirmektedir. Toplumu anlatma biçimlerini harita çizmeye benzeten Becker, hangi haritayı kullanmak gerektiğini soranlara şu cevabı vermektedir: "Duruma göre değişir. Yani haritaya neden ihtiyaç duyduğuma bağlı olarak hangi haritayı tercih edeceğim değişecektir. Eğer arkadaşımın evine gitmek için haritaya ihtiyaç duyuyorsam, o zaman arkadaşım tarafından çizilmiş ve bütün yerel işaretleri içeren haritayı tercih ederim. Eğer kentsel istatistikleri hesaplayacaksam, o zaman da bir haritacının yaptığı haritayı tercih ederim" (2016, s.363-364). Dolayısıyla toplumu anlama ve anlatma biçimleri haritanın yapısına göre değişebilmektedir. Bazen bazı yerlerin tarifi her ne kadar harita üzerinde kolay gözükse de pratikte bu böyle olmamaktadır. Yolu göstermesi noktasında kolaylık tanısın diye faydalanılmak istenen haritalar, işleri daha da içinden çıkılmaz hale getirebilmektedir.

Toplum kavramına getirilen açılamaların hangi haritayı temel aldığı, toplumun içeriğine dair yapılacak yorumların manevra alanını daraltıp genişletebilmektedir. Topluma dair yapılacak tanımlama ve açıklamaların hangi haritaları kullanacağı, toplum içindeki bireye bakış açısını ele vermektedir. Toplumun tamamını açılamaya azmetmiş geniş ölçekli makro haritalarda birey ve bireyin geçirdiği değişimler görünmemektedir. Nitekim makro sosyolojik teorilerin yararlandığı haritalarda birey ve gündelik yaşama dair yol işaretlerine pek rastlanmamaktadır. Ancak toplumun tamamını açıklama iddiasından ziyade, toplumun belli bir kesitini ve kesimini gündemine alan haritalarda birey ve gündelik yaşama dair ince-detaylı ayrıntıların göze çarptığı görülmektedir. Bireyin toplum 
içindeki yeri, grup-içi ve dışı ilişiklerin sınırları, yalnızlık, birliktelik, ötekilik gibi işaretler, mikro güzergâhları gösteren haritalarla mümkün olabilmektedir.

Toplumu anlamak için analizlerini gündelik yaşamdaki anlam stoklarına odaklayan yani detaylı bir haritayla bakan Berger ve Luckmann (2015, s.24-31) gündelik hayatın birbirine bağlanmış sayısız eylem zincirinden ibaret olduğunu dile getirmektedir. Onlara göre kişinin bireysel kimliği zikredilen eylem içerisinde biçimlenmektedir. Böylelikle toplumsal olarak nesnelleştirilen ve işlenen anlam stokları, tarihsel anlam rezervlerinde muhafaza edilmekte ve kurumlar tarafından yönetilmektedirler. Bireyin eylemleri, toplumsal bilgi stoklarından tedarik edilen nesnel anlamca şekillenmekte ve kurumlarca ortaya çıarılan şeylere intibak olma baskısı yoluyla iletilmektedir. Bu bağlamda sadece yapı içerisindeki bireyden ziyade fail olan bir aktörün varlığı söz konusu olmaktadır. Özellikle Simmel'in mikro analizleri, gündelik yaşam içerisindeki anlam stoklarının nasıl ve ne şekilde inşa edildiğinin görülmesi açısından önemli olmaktadır. Nitekim Sayer ve Frisby (2017, s.65) Simmel'in geliştirdiği sosyolojiyle toplumu; bir nesne, mutlak ve varsayımsal bir bütünlük olarak ele alan anlayıştan uzak bir temele dayandırdığını dile getirmektedir. Yazarlara göre Simmel, etkileşim ve toplumlaşma biçimlerini inceleyen bir disiplin öngörmüşve kendi anlayışını dönemin sosyolojik geleneklerinden ayırabilmek adına toplum ile tarihin gelişimi için anahtar görevi gören kanunlar olduğu iddiasını reddetmiştir.

Meşhur "Metropol ve Tinsel Hayat" (Simmel, 2009) adlı makalesinin yayınlandığı zaman sansasyonel bir etki oluşturmaması, metnin kalitesi ile alakalı değil, dönemin hakim paradigmasınca bastırılması nedeniyledir. Zira Simmel yaşadığı dönem itibariyle mevcut paradigmayı ve paradigmanın işaret ettiği haritayı tersyüz edecek açıklamalarda bulunmuştur. Kendi döneminin belki de "birey"e dokunan, bireyi ele alıp masaya yatıran en önemli ismidir. Kentleşme ve metropol hayatının getirdiği yeni ilişkilerin aynı zamanda yeni bir birey tarzını doğurduğu üzerine uzun uzadıya analizler yapmıştır Simmel. Bireyin ve dolayısıyla bireyselliğin belki sosyolojik olarak ele alınması Simmel sayesinde olmuştur demek abartı olmayacaktır. Metropol hayatındaki ilişkilerin aktörü olan bireyin, yakın ve uzak ilişkileri nasıl tesis ettiği, bireyin ait olma ve ayrı durma gibi pratiklerini belirlemektedir. Yani grup içinde kalma ve 
yalnızlığın sınırları, kent yaşamındaki gündelik ilişkilerce belirlenmektedir. Özellikle metropolde aşırı uyarıcıların istilası altındaki bireyin, bir müddet sonra uyarıcılara karşı duyarsızlaşmasının kaçınılmaz olduğu varsayımıla dikkatleri çekmektedir. Zira Simmel sonrası analizlerin, toplumu ve bireyi açıklama biçimlerinin önemli bir yekûnu, Simmel metinlerine referans vermek durumunda kalmışlardır.

\section{Bireyselleşme ve Yalnızlığın İmarı}

Simmel nicel ve nitel bireysellik ayrımı yapmaktadır. Simmel'e göre bir yanda kişiliğin bireyselleşmesi, öte yanda kişiliği toplumsal çerçevesine bağlayan etkiler, çıarlar ve ilişkiler, birbirine bağımlı bir gelişme örüntüsü vermekte ve bu örüntü çok farklı tarihsel ve kurumsal ortamlarda tipik bir biçim olarak ortaya çıkmaktadır. Bireyi kuşatan çevre ne derece genişlerse genelde varlık ve eylemdeki bireysellik de o derece artmaktadır (Simmel, 2009, s.232-241). Bireyin kendisini bağladığı çevre ne kadar darsa, o kadar az bireysellik özgürlügüne sahip olur; ne var ki bu daha dar çevrenin kendisi de bireysel bir şeydir ve tam da küçük olduğu için kendini bütün diğer çevrelerden keskin bir şekilde koparmaktadır. Buna karşılık, aktif olunan ve çıkarların hüküm sürdüğü çevre genişlerse, onda bireyselliğin gelişmesi için daha çok yer olacaktır. Ama bu bütünün parçaları olarak, benzersizliğimiz daha da azdır: Toplumsal bir grup olarak bu daha büyük bütünün bireyselliği daha az olmaktadır. Etrafımızın eşmerkezli özel çıkar halkalarıyla çevrili olduğunu ifade eden Simmel'e göre insan, ne sadece kolektif ne de sadece bireysel bir varlıktır.. İkisinin kesişim noktasında salınmaktadır.

Bireyin toplumsallaşma sürecinde, onun nerede ve nasıl konumlanması gerektiğini kodlayan toplum tiplerine gelenek, iç ve diş yönelimli toplum modelleri ile yaklaşan Riesman ise bireyi tanımlayan toplumsal yapıların karakter biçimleri üzerine dikkatleri çekmektedir. Riesman'a göre (2016, s.24) toplumsal karakter kavramı; sinıfların, grupların, bölgelerin ulusların karakterlerini anlama ve tanımlama imkânı sunmaktadır. Toplumsal karakter kalıtsallıktan ziyade deneyimlere atfedilebilmekte veya varlığı deneysel yollarla kanıtlanabilmektedir. Hatta dünyadaki tüm insanları bir arada tutan yahut onları birbirinden ayıran karakter ve kişilik öğelerinden daha önemli görülmeyi hak etmektedir. 
Riesman, karakter ve toplum analizi yaparken bunu üç kategoride toplamaktadır: Gelenek yönelimli, içe yönelimli ve dışa yönelimli karakter yapıları.

Toplumsal yapıların analizini ve bu toplum tiplerindeki bireylerin nasıl toplumsallaştıklarını ele alan Riesman, esasında modern öncesi, modern ve modern ötesi olarak tanımlanabilecek insan tiplerinin haritasını çıkarmaktadır. Riesman'a göre (2016, s.32-35) gelenek yönelimli toplumlarda bireylerin, dâhil oldukları grupların diğer üyeleriyle aralarında iyi tanımlanmış fonksiyonel bir ilişki söz konusudur. Burada bireyin her zaman ait olduğu bir grup vardır. Modern toplumlarda işsizler fazlalık; vasıfsız olanlar ise işe yaramaz görülürken gelenek-yönelimli toplumlarda durum tam tersidir: Bireyler ne fazlalık olabilir ne de işe yaramaz. Bu toplumlarda grubun göstereceği herhangi bir ilerlemenin sınırlı olması gibi, aidiyetinin sonucu olarak bireyin tercihleri de kaderini sınırlı ölçüde şekillendirmektedir. Dolayısıyla gelenek yönelimli toplumda birey, kararları üzerinde sınırsız bir yetkiye sahip değildir. Akabinde modern dönemi imleyen içe-dönük toplumsal karakterde birey, bağımsız bir şekilde karar vermesi istenendir. Bu toplum tipi, Rönesans ve Reform'un ürünüdür. Uyumu güvence altına almak için içe-yönelimi temel yöntem olarak benimsemiş bir toplum biçimini temsil etmektedir. Böylesi bir toplum, bireysel hareketlilik, hızlı sermaye birikimi ve sürekli bir ilerleme hali ile nitelendirilmektedir. Toplumun, sunduğu daha fazla seçenekler ile yeni sorunlarla baş etmek için talep ettiği çözümler; gelenekyönelimi içerisine hapsolmadan sosyal olarak yaşamayı başarabilen karakter biçimleriyle idare edilmektedir.

Söz konusu toplum tiplerinin ürettiği birey tipleri de ziyadesiyle farklılaşmaktadır. Riesman (2016, s.37-46) gelenek yönelimli bireyin, kendisini bir birey olarak düşünmediğini ifade etmektedir. Burada bireyin, kendi kaderini belirleyebileceği yahut çocuklarının kaderinin farklı olabileceği aklına gelmemektedir. Bu noktadan bakabilecek kadar ailesinden, ait olduğu gruptan psikolojik olarak henüz kopmamıştır. Geçici nüfus artışı evresindeki içe-yönelimli toplumda ise insanlar kendi yaşamları üzerinde kontrolleri olduğu hissine kapılmaktadırlar ve çocuklarını kariyerleri olan bireyler olarak görüp onları kontrol etmektedirler. Hakeza dışa-yönelimli kişi için ise aile, sıkı sıkıya bağlı olduğu bir birim değil, başından beri özen gösterdiği geniş sosyal çevrenin sadece bir 
parçasıdır. Dışa yönelimli birey bu yönüyle kozmopolittir. Bu birey için tanıdık olan ile yabancı gelen arasında bir sınır kalmamıştır. Ancak gelenek yönelimli bireyin yaşadığı toplumda iki grup arasına net bir sınır çekilmiştir. İçe-yönelimli kişi diğer insanlara duyarsızlığı neticesinde ortamın içinde ve dışında kalabilirken, dışa-yönelimli insan her yerde ortama dâhil olmaktadır.

Son dönemin önemli sosyologlarından biri olan Bauman'a göre bireyselleşme artık yüzyıl önceki anlamından yani modern çağın erken zamanlarından, insanların cemaatçi bağımlılık, gözetleme ve pekiştirmeden oluşan sıkıca bağlanmış ağından kurtulup özgürleşmesinin çok övüldüğü zamanlarda sahip olduğu anlamdan çok farklı bir anlam taşımaktadır (Bauman, 2015, s.66). Artık, bireyselleşme fikrinin içerdiği şey; bireyin toplumsal karakterinin, atfedilerek, miras alınarak belirlenme durumundan kurtulmasıdır. Bireyselleşme, insan kimliğinin, bir veriden bir göreve dönüştürülmesine evirilmiştir. Ve aktörlere yeni sorumluluk alanlarının tayin edilmesini beraberinde getirmiştir. Aktörler yaptıklarının sonuçlarını peşinen kabullenmiş olurlar (Bauman, 2015, s.192). Dolayısıyla bireyselleşmenin erkek ve kadınlara daha önce görülmemiş bir deneme özgürlüğün verdiğini ifade eden Bauman'a göre (2015, s.72) deneme özgürlüğü, sonuçlara katlanma ve sonuçları kabullenmeyi de şart koşmaktadır. Bireyselleşme, Bauman'ın yeni toplum tiplemesinde merkezi rol oynamaktadır. Bireyselleşmiş Toplum (Bauman, 2001); durum, düşün ve eylem dünyasında bireyin artık meta oluşumlardan sıyrılarak kendini inşa etmesi üzerine yoğunlaşmaktadır. Bauman gibi çağdaş bir düşünür olan Sennett, Kamusal İnsanın Çöküşü'nde (2010), yeni yaşam tarzlarının kamusal kültürü ortadan kaldırdığını, narsizmin yükseldiğini ve -önemli bir uygarlık oluşturan ve kamusal alan olanşehrin uykuya geçtiğini belirtip ekler: "Gizemli, tehlikeli bir güç olan benlik, adım adım toplumsal ilişkileri tanımlamaya başladı. Toplumsal bir ilke oldu. Bu noktada da, kişi dışı anlamları kapsayan kamusal alan ve kişi dışı eylemleri zayıflamaya başladı" (2010, s.434).

Bireyselleşme şüphesiz çok daha eski bir tartışma konusudur. Bu tartışmayı sosyolojinin bir bilim olarak ortaya çıktığı dönemlere kadar götürebilmek mümkündür. Bu noktada önemli bir referans oluşturan Simmel'in kült çalışması Bireysellik ve Kültür'ü zikretmek gerekmektedir. Düşünce tarihinin müthiş kavrayışlarından biri olarak gördüğü 
bireyselliği Simmel şöyle açıklamaktadır: “İnsan bütünüyle kendisi olmayan her şeyden kurtulduğunda, varlığının fiili cevheri olarak geriye kalan genel insandır, onda ve başka herkeste yaşayan insanlıktır, sadece ampirik-tarihsel nedenlerle gizlenmiş, azalmış ve çarpitılmış olsa da hep özdeş kalan temel özdür" (2009, s.213). Aynı dönemlerde Tocqueville (2016), bireysellik olgusunu, sivil katılımdan geri çekilme olarak görmüştür. 1830'lar gibi erken bir tarihte Amerika'da Demokrasi adlı eserinde yalnızlık konusuna parmak basan Tocqueville, bir mektubunda insanlar arasında yalnızlığın çöldeki yalnızlıktan daha acımasız olduğunu ileri sürmektedir (Svendsen, 2018, s.12-13).

Bireyselleşmenin yeni ve farklı tanımlamaları, topluma yeni tanım ve yaklaşımları beraberinde getirmektedir. Bireyselleşmenin, modern dönemde ifade ettiği özgürleşim söyleminin çok daha ötesine geçtiği ve yeni bedeller ödettiği söylenmelidir. Bauman'ın özgürlüğün sonuçları dediği ve uyardığı şey, son dönemde yapılan toplum analizlerinin başkarakteridir: Yalnızlık. Son dönem çalışmalardaki toplumsal dönüşüm ve değişimler ele alınırken toplumdaki bireylerin yalnızlığından dem vurulmaktadır. Toplumu anlamanın ve açıklamanın yeni şekli; yalnız ve kendisini göstermeye çalışan bireylerin, ilgi çekmek isteyenlerin, güvenlik endişeleri söylemlerinin sonuna "toplum" kavramının getirilmesidir. Bireyselleşme ve yalnızlığın arttığı üzerine ittifak eden son dönem çalışmalarda sorun merkezli toplum tanımlamaları revaçtadır. Dolayısıyla ilk dönem sosyolojisinde her şeye gücü yeten ve her şeyi açıklayan "toplum" kavramı artık gündelik yaşamdaki ilişkilerin ve duyguların ifade edilmesinde kullanılan yardımcı bir kavram halini almıştır.

Aydemir, toplum doğasını anlamaya çalışan sosyal bilimlerin, birey ve toplum ilişkisi ekseninde ortaya koyduğu kuramların, temelde bir arada yaşamanın gerekleri ve sonuçları üzerine düşünme pratiklerini içerdiğini ifade etmektedir. İncelemeye konu olan toplumsal dünya, bireylerarası ilişkilerin, etkileşimlerin, ağların, yapı ve kurumların gerçeklik kazandığı bir alandır. Toplumsal alanın bilgisini anlamaya çalışan her bilimsel disiplin çoğunlukla kendi kavramsal dizgesini merkezi önemde tutarak analize yönelmektedir (Aydemir, 2011, s.7). Son dönem toplumsal 
yaşamdaki ilişkilerin içeriği, mesafesi vb. nitelikler sosyal sermaye ${ }^{3}$ kavramı etrafında dönmektedir. Bireyin yalnızlığı, gruba aidiyeti, kültürü, ürettikleri ve tükettikleri, sosyal sermaye kavramının sorumluluk alanına dâhil edilmiştir. Mesela sosyal sermaye teorisyenlerinden Putnam, cemaatin zayıfladığını ve toplumsal ağlarda genel bir erozyonun yaşandığını bowling üzerinden açıklamaktadır (2000). Bir başka isim olan Bourdieu, sosyal mesafelerin, gündelik tüketim alışkanlıklarınca kültürel sermaye etrafında şekillendiği çıkarımında bulunmaktadır. Toplumsal ilişkilerin dönüşümü ve bireyin değişimdeki yeri genel itibariyle bireyin duygu dünyası ve çevresiyle kurduğu diyalog çerçevesinde yeni anlamlar ve tanımlar kazanmaktadır. Bireyselleşmenin baskıcı bir toplumda bireyin lehine değişen süreçleri imlediği zamanlar geride kalmış ve bireyselleşme terimi sosyal bilim literatüründe gittikçe pejoratif hal almaya başlayan yeni bir kavramla anılmaya başlamıştır: Yalnızlık.

\section{Yalnızlık İmgesi}

Bir başınalık, tek başınalık, yapayalnızlık, izolasyon gibi dereceleri vardır yalnızlığın. Yalnızlık, bir şeyleri birilerine açmanın gereksiz yahut yetersiz olduğunun düşünüldüğ̈u zamanlarda kendisini gösterebildiği gibi farkındalığın gerçekleşebilmesi anlamında olumlu bir imgeye de işaret etmektedir. Bireyin kendisini dinlemesinin, hayatı anlamlı kılan şeyleri keşfetmenin bir yolu olabileceği gibi; çatışmanın, kavganın, hayatla yaka paça olmanın, bunalımın tetikleyicisi de olabilmektedir. Yalnızlık hemen herkesin hayatında en az bir kere tecrübe ettiği bir duygudur. Yalnız olmak, paylaşıma kapalı olmak, birilerinden bir yerlerden uzak olmak demektir. Yalnızlığın türleri ve türevleri, yalnızlığa maruz bırakılma ve yalnızlık istenci duygu durumunun karmaşık oluşundan ziyade toplumsallaşma biçimlerine göre değişmektedir. Yakın yüz yüze ilişkilerin yaşandığı kapalı toplumlarda yalnızlık neredeyse bir lükstür. Buna mukabil ilişkilerin ikincil kanallar üzerinden ve resmi tarzda sürdürüldügü toplumlarda ise yalnızlık hayatın olağan akışına uygun bir süreç kabul edilmektedir.

${ }^{3}$ Sosyal sermaye ve yalnızlık üzerine birçok çalışma kaleme alınmıştır. Bunlardan en önemlileri: Bourdieu (2002), Coleman (1988) ve Putnam'ın (2000) çalışmalarıdır. 
Toplumu açıklama biçimleri yalnızlık tanımını bu bağlamda kendince üretmektedir. Toplumu her okuma biçimi, yakınlık ve uzaklık kavramlarını kendince yeniden tanımlamaktadır. Sosyal mesafelerin nasıl kurulacağı, mesafenin uzaklık ve yakınlık ölçülerinin ne kadar olacağı, kurulan teorik bakış açısınca kestirilmektedir. Yalnızlığın bireysellik temelinin yanı sıra, dini ve dünyevi bütün öğretilerin önemli bir kısmında yalnızlı̆̆ın farklı türleri üzerinde durulmaktadır. Semavi dinler, insan neslinin devamını yalnızlık teması üzerinden kurgularken, peygamberlerin yalnız olduklarından bahsetmektedir. Münzevi bir hayat sürmenin, dindarlık düzeyi hakkında ciddi bir veri olduğu kabul görmektedir. Statünün, yabancı olmanın, yalıtılmanın, modern yaşamda sabır kavramının, yaş, cinsiyet, gelir dağılımı, güvenlik gibi kavramlar doğrudan ve dolaylı olarak yalnızlıkla ilintilidir. Yalnızlığın olumlu ve olumsuz yanlarının olduğu söylenmektedir. Terk edilmişlik anlamında yalnızlık olumsuz iken, inziva ve kendi ile baş başa kalma anlamındaki yalnızlık olumlu değerlendirilmektedir. Modern dışı toplumlarda bireysellik pejoratif bir mahiyet kesbederken, modern toplumlarda istenen bir sürece işaret etmektedir. Toplumların kendilerini tanımlama ve konumlandırma biçimleri, yalnızlık kavramına olan yaklaşımın mahiyetini belirlemektedir.

Bireyselleşme, yabanclık kavramları üzerine epey kafa yoran Simmel, bu kavramın şekil bulduğu topluma dair iki farklı değerlendirmenin yer aldığını söylemektedir. Simmel'e göre (2009, s.134) toplumun doğası üzerinde eskiden beri süren bir çatışma vardır. Bir taraf toplumun önemini gizemci bir biçimde abartıp insan hayatının ancak toplum yoluyla gerçeklik kazandığını savunurken; öbür taraf, topluma, gözlemcinin insanlardan ibaret olan gerçeklikleri bir bütün haline getirmesini sağlayan soyut bir kavram gözüyle bakmaktadır. Dolayısıyla insan, bu çatışmada ne karar verirse versin, toplumun iki anlamda da bir gerçeklik olduğunu teslim etmek durumundadır.

Bireyselleşmenin doğuşu hakkında Rönesans çağının milat olduğu noktasında ittifak edildiğini dile getiren Simmel'e (2009, s.211) göre buradaki bireyselleşmeden kasıt, ortaçağın karanlığından, homojenletirici grupların despotizminden kurtulmuş olmak kastedilmektedir. Çünkü bu toplumsal formasyonda, ortodoksinin hâkimiyeti altındaki bireye ve bireyin beklentilerine ket vurulmuştur. Rönesans'la beraber birey; göze çarpmak, kendini yerleşik biçimlerle mümkün olabileceğinden daha cömert ve daha dikkate değer bir şekilde sunmak istemiştir. Böylece Rönesans insanın hırsına, kendine 
amansızca düşkün oluşuna, eşsiz, biricik olamaya yaptığ1 ve değer yargisı içeren vurguya bağlanan, temayüz etme odaklı bireyciliğin doğuşu gerçekleşmiştir. Nitekim Sønderby (2013) kötü olarak kabul edilen geleneklerin yıkılışının bireyselliği hızlandırdığı kaydını düşmektedir. İnsanlar artık belli sınıf yahut kategori çerçevesinde tanımlanmamaktadır Bu gelişme, bireyci bir toplumu talep eden refah devleti anlayışınca da teşvik edilmektedir. Buradaki odak ise ailesel yahut grupsal haklar yerine bireysel haklar üzerindedir.

Bireyselleşmenin akabinde, daha önce ifade edildiği gibi, Bauman'ın bahsettiği bedellerden belki de en önemlisi ile yani yalnızlık kavramıla karşı karşıya kalınmıştır ${ }^{4}$. Yalnızlık yeni bir olgu olmasa da bireyselleşmenin oldukça yükseldiği yeni toplum tipinde sık görülen ve hatta bazı mekânsal ve kültürel yapılarda oldukça sıradanlaşan bir olguya dönüşmektedir. Öyle ki günümüzde yalnızlığın önemli bir olguya dönüştüğü ülkelerden bahsetmek mümkündür. Örneğin, İngiltere Başbakanı Theresa May, 2018 başlarında sosyal izolasyonla mücadele etmek için yalnızlık ile ilgilenecek bir bakan (Minister for loneliness) atamıştır (Erişim 1). Bakanlık 2019 yılbaşında vatandaşlarına bir tavsiyede bulunarak aile tatillerine büyükanne ve büyük babaların da götürülmesi gerektiğini vurgulamıştır (Erişim 2). Yalnızlık, İngiltere gibi bakanlık seviyesinde olmasa da dünya üzerinde birçok hükümetin önemsediği bir olgu haline gelmektedir. Yalnızlığın çıkış noktası kanaatimizce yeni toplum tipinin en önemli olgusu/süreci olan bireyselleşmedir. Yüz yüze ilişkilerin oldukça zayıfladığı, kapitalistleşme ve sekülerleşmenin körüklediği bireysel çkarların ön planda tutulduğu, tahammülsüzlüklerin, risklerin arttı̆̆; güvenin, ve soy birlikteliklerinin azaldığı bir dönemde yalnızlık, bireyselleşmenin kaçınılmaz bir sonu olarak yeni toplum tipolojilerinin ontolojik yapıtaşlarından birini oluşturmaktadır.

\section{Yalnızlık: Nedir, Ne Değildir?}

Yalnızlığın ontolojik olarak güven ile bir ilişkisi söz konusudur. Güven düzeyinin artmasına mukabil yalnızlık düzeyinde azalmalar gerçekleşirken,

\footnotetext{
${ }^{4}$ Svendsen $(2018$, s.14) yalnızlığa farklı bir bakış açısıyla yaklaşmaktadır. Ona göre yalnızlığa dair çalışmalarda artışın görülmesi yahut mezkûr probleme dair farkındalığın artması, yalnızlığın arttığı gibi bir değerlendirmeyi haklı kılmayabilmektedir. Farkındalığın artışı veya problemin dillendirilmesindeki artış, problemin arttığı anlamını her zaman vermeyebilmektedir.
} 
güvenin azalması, beraberinde yalnızlaşma oranında artışın yaşanmasını getirmektedir. Modern zamanda kentlerde güven düzeyinin azalmasını artan bireyselleşmeye ve yabancliğa dayandıran bakış açıları, bu toplumsal değişimi; gözetim toplumu, panoptikon, kontrol toplumu, risk ve belirsizlik toplumu gibi terkiplerle karşılamaktadırlar. Mesela Arendt, totaliter toplum ve devletlerin bireyleri kitlesel bir yalnızlığa ittiğini dile getirirken (2014) konuya gündelik yaşamdaki etkileşimler bağlamında yaklaşan Goffman'a göre (2017a, s.122) yalnızlığın mahcubiyetle bir bağlantısı vardır. Yalnızlık üzerine ampirik çalışmalar ise Peplau ve Perlman tarafından 1980'lerde gerçekleştirilmiştir. Peplau ve Perlman'a göre yalnızlık, bireyin var olan sosyal ilişkisi ile arzuladığı sosyal ilişki arasındaki tutarsızlıklar sonucunda oluşan ve hoş olmayan öznel psikolojik durumdur (De Jong Gierveld vd, 2006). Peplau ve Perlman'a göre (1979) yalnızlığın tezahürleri üç ana kategoriye ayrilabilir: Duygusal, bilişsel ve davranışsal. Yalnızlık duygusal olarak tatsız bir deneyimdir. Yalnızlık özellikle, memnuniyetsizlik, mutsuzluk, depresyon, anksiyete, boşluk, can sıkıntısı gibi şeylerle bağlantılıdır.

Yalnızlık deneyimini göz önüne alarak Weiss, sosyal izolasyon yalnızlığı ile duygusal izolasyon yalnızlığı arasında ayrım yapmaktadır. Sosyal izolasyon yalnızlığı, Weiss'e göre ilgi çekici bir sosyal ağın olmayışından kaynaklanmaktadır. Buna karşın duygusal sosyal yalnızlık ise yakın bir bağlanma ilişkisinin yoksunluğundan kaynaklanmaktadır. Bu tip bir yalnızlık, Weiss'in iddiasına göre ancak tatmin edici bir bağlanma ilişkisinin kurulmasıyla hafifletilebilmektedir (DiTommaso ve Spinner, 1997). Weiss'e (1973) müteakip çalışmalarda yalnızlık, sosyal ve duygusal olarak iki ayrı biçimde ele alınmıştır. Duygusal yalnızlık; bireyin başkalarına yakın duygusal bağlanmalarının olmamasından, sosyal yalnızlık ise; bireylerin diğer insanlarla sosyal ilişkisinin az olmasından veya olmamasından kaynaklanan yalnızlık kategorileridir. Rokach da (2014) yalnızlığa dair bir takım maddelerde ortak bir kanaate varıldığını dillendirmektedir. Bu konsensüse göre: yalnızlık bir ayrılık deneyimidir, bağlayıcı anlamların yitimidir, yalnızlık acı vericidir ve tahammülü zordur, yalnızlık bireyi bir anlam arayışına itmektedir.

Svendsen (2018, s.18-19) İngiliz dilinin loneliness ile solitude arasında ayrım yaptığın kaydetmektedir. Loneliness (yalnızlık) daha çok olumsuz duygusal bir hali belirtirken, solitude (kendi başına olma, tek başınalık) pozitif hali imlemektedir. Bu noktada yalnızlık ve inziva kavramlarını 
ayrıştırmak gerekmektedir. Yalnızlık ve inziva toplumu okumanın iki farklı paradigmasına işaret etmektedir. Heidegger, niçin taşrada yaşadığını soranlara, kent yalnızlığının aksine taşrada münzevi bir hayatı tattı̆̆ cevabını vermektedir (2012, s.206). Yine İslam coğrafyası içerisinde inzivanın, yalnızlıktan farklı bir kategoride değerlendirildiğini Gazali (2014) etraflıca ele almaktadır. Yalnızlık deneyimlerinin farklı coğrafyalarda çok farklı anlamları haiz olduğunu dile getiren Yaşar'a göre (2007, s.242) “yalnızlık Akdeniz kültürleri gibi bireysel mesafenin dar ve ilişkilerin yakın olduğu ortamlarda genel olarak terk edilmişliği, kimsesizliği çağrıştırırken Batı toplumlarında, bireyleşmek, kendi ayakları üzerinde durmak anlamlarına" gelmektedir.

Younger (1995), yalnızlığı, bir yakınlık oluşturmayan his olarak tarif ettiği yabancllık ve sosyal ortamlardan yalıtılmayı ifade eden sosyal izolasyondan farklı bir yere koymaktadır. Sennett, Younger'a paralel olarak yalnızlık olgusunu izolasyon ve tek başınalık olgularından ayrı tutmaktadır (2012, s.226). Dove'a (2015) göre de olumsuz anlamları içkin olan yalnızlığın (loneliness) aksine bir başınalık (aloneness) içinde yaşam sevincini, kendine yetmeyi, kimseye ihtiyaç duymamayı anlatmaktadır. Killeen (1998, s.765) toplumsal algı üzerine yaptığı çizgisel süreçle bir bakıma yalnızlığın, yalnızlığa benzetilen diğer durumlardan farklılaştığını göstermektedir:

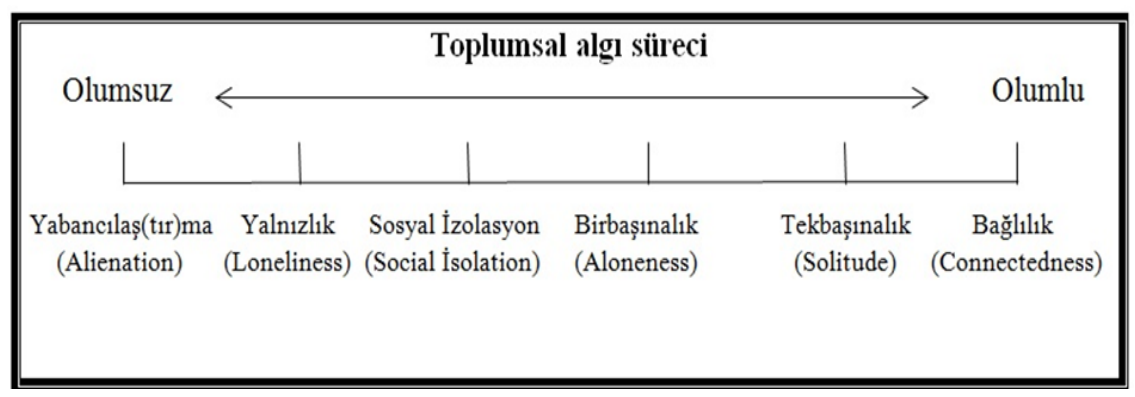

Toplumsal algıda yalnızlığın nasıl bir skalada seyrettiğinin ele alındığı yukarıdaki tablo; toplumsal kodların, yalnızlık hallerine olan reflekslerini ele vermektedir. Genel itibariyle geleneksel toplumun değerleri ve algılarına hasredilebilecek bu tabloda bireyin yabanclaşmayı çağrıştıran yalnızlığı kabul görmezken, bir arada bulunma ve grup dayanışmasının güçlendirilmesine dair retoriğin güçlü olduğu yorumu yapılabilmektedir. Ancak Oskay'in da ifade ettiği üzere (1994, s.5) on dokuzuncu yüzyıldan bugüne kadarki 
modern topluma geçiş süreci içerisinde insanlar, köylerindeki; eş-dostlarını, geleneksel hayatta kasaba ve kentlerde bile devam eden hisım-akraba bağlılık ve yakınlıklarını, aynı mekânda yıllarca yaşamakta olmanın kazandırdığı arkadaşlık bağlarını, dayanışmalarını, hemşerilik duygularını yitirmeye başlamışlardır. Modern dönemin kentleri ile birlikte yalnızca kentlerde yaşayan insanlar için değil, para ekonomisine geçen kırsal kesimin yerleşmelerinde yaşayan insanlar için de yabancılaşmanın gitgide daha yoğun yaşandığ1 bir sürece girilmiştir. Bugün gelinen süreçte modernitenin yaşandığı dönemin ve klasik sosyal bilimlerin toplumu açıklama biçimlerinin çok ötesine geçilmiştir. Bu yeni toplumunun yaşam biçimleri ciddi bir değişime uğramıştır. Güvenlikli siteler (Alver, 2007), ilişkilerde artan sosyal mesafeler (Bogardus, 1933), şöhret olma taleplerindeki patlamalar (Rojek, 2003) ve yeni teknolojilerle beraber artan sosyal medya etkileriyle beraber, kalabalıklar içindeki yalnızlık yeni toplumun kanonu haline gelmiştir.

Yalnızlık şüphesiz bütünüyle olumsuz bir durum değildir. Yaratıcı yalnızlık gibi yalnızlık türlerine dikkat edildiğinde yalnızlığın, üretim için önemli bir ortam oluşturduğu söylenebilmektedir. Bununla birlikte birçok dinsel söylemde, yalnız kalmanın ibadet etme ve Tanrı'ya yakınlık kurma noktasında önemli bir firsat olarak değerlendirildiği bilinmektedir. Toplumun yeni okunma biçimlerinde ise bir tercih biçimi olarak şekillenen yalnızlık olgusu; keşmekeşliğin, kalabalığın, sağlıklı yaşamın, dinlenmenin, ideolojilerden ve mahalle baskısından sıyrılmanın vs. bir çıkış noktası olarak karşımıza çıkmaktadır. Fakat bu durumlar yalnızlıkla ne kadar ilintilidir? İnziva, kaçış, tek başınalık, yabancılık, dışlanmışlık gibi durumlar yalnızlık olgusuyla ilintili olmak ve yalnızlık olgusuna benzerlik göstermekle birlikte daha önce belirttiğimiz gibi yalnızlıktan farklı özelliklere sahiptirler. Yine de insanların bu olguyla hemhal olması artık yeni toplum biçimlerinde bir popülerliğe sahiptir. Dolayısıyla önceleri bir anomi şeklinde beliren yalnızlık olgusu, günümüzde popüler olmanın göstergesidir. Yalnızlık, mekânsal bağlamda, kent ve metropollerde bir zorunluluk arz etmektedir. Bugün büyük kentler başta olmak üzere birçok yerleşim yerinde birden fazla kişinin yaşayamayacağı konutların oluşturduğu rezidanslarla karşı karşıyayız. Goffmanvari (2017b) toplumsal düzen arayışları ve tanımlamaları artık yeni yalnızlık halleri üzerinden üretilmektedir. Kalabalıklar içinde ama farklı, yalnız ama dikkat çekmek isteyen, kaçan ama kovalanmak isteyen, seven ama 
zora gelince hayatına dâhil etmeyen yalnız bireyin başrolde olduğu yeni toplum anlatıları, güçlü senaryolar olarak arz-1 endam etmektedirler.

\section{Sonuç}

Toplumu okuma biçimleri, birbirinden farklı perspektif ve paradigmalardan beslenmektedir. Topluma dair her değerlendirme biçimi, toplumu belli bir noktasından tutarak işe koyulmaktadır. Belli problematikler ve fenomenler etrafında yapılan değerlendirmeler toplumu anlatma ve açıklamanın biçimleri olarak da gösterilmektedir. Toplumu anlama ve açıklamanın sınırları, içerisinden bakılan paradigmanun referanslarınca belirlenmektedir. Sosyal bilimlerin doğuş sürecinde topluma ve bireye dair yapılan değerlendirmelerde ibre daima yapının yani toplumun lehine dönmekteydi. Toplumun yapısı ve içeriğine dair yapılan çalışmaların ekseriyeti yapıya odaklanmaktaydı. Toplumun ne olduğu, nasıl olması gerektiği, toplumsal bütünlügün ve çatışmanın ne şekilde cereyan ettiği gibi soruların cevabı bireyi genel itibariyle teğet geçmiştir. Mekanik ve organik dayanışma, tarihsel materyalizm, geleneksel-karizmatik-rasyonel meşruiyet tipleri esasında toplum tipolojilerine denk düşmektedir. Ancak modernleşmenin getirdiği yeni kentli birey tipi, toplumu yeniden gözden geçirmenin gerekliliği konusunda uyarılarda bulunmuştur.

Modernleşme ve bireyselleşmenin getirdiği yalnızlık olgusunun, "yeni toplumun temel dokusu"nu oluşturduğu kabulü artarak devam etmiştir. Topluma dair yapılan ve yapılacak olan analizler bireyselleşmenin getirdiği yalnızlık hallerine odaklanmaktadır. Geleneksel dünyadaki toplumsal yapının olumsuz ötekisi olan birey, modern dönemde başrole geçmiştir. Topluma dair yapılan yorum ve yaklaşımların genel kabulü yalnızlığın temel belirleyen olduğudur. Risk toplumu, şeffaflık toplumu, ağ toplumu, kontrol toplumu gibi kavramsallaştırmaların dayandıkları temel referans kaynakları, yalnızlığın serdedilme tarzlarıdır. Toplumu her tanımlama biçimi esasen yalnızlığın nasıl anlaşıldığı ve anlaşılması gerektiği bilgisini de vermektedir. $\mathrm{Bu}$ bakımdan yalnızlık, yapılan toplum tanımlarına göre her seferinde yeni anlamlar kazanmaktadır. Kimi yaklaşımlar toplumu açıklamada yalnızlı̆̆ı, güvensizlik ve risk gibi kavramlarla finanse ederken; kimi analizler yalnızlığ birey ve özgür olmanın, ayakları üzerinde durmanın kanonu olarak konumlandırmakladır. Yalnızlık kimi yerde imrenilecek bir şey iken, kimi yerde 
Ejder Ulutaş - Ahmet Gökçen

iğrenilecek bir imgeyi çağrıştırmaktadır. Netice itibariyle toplumu anlatma çabası ve toplum halleri, yalnızlık hallerine göndermede bulunmaktadır. 
EXTENDED ABSTRACT

\title{
Society Types and States of Loneliness
}

\author{
Ejder Ulutaş - Ahmet Gökçen
}

Muş Alparslan University

Every attempt to explain society in the modern era produces new theories or leans on several existing theories. Under the influence of Western Cartesianism, classical theorists explained and understood society through the concept binary. The distinction between traditional and modern world is that the distinction is configured through everyday life practices. The answers to the questions of what the traditional and the modern are, in most cases, reveal the ways in which the relationships in everyday life manifest. When referring to the traditional world, the relations are face to face, close and emotional, modern period is defined with reference to secondary or official relations. However, it is necessary to state that we are faced with new social definitions that have never been similar to their spouses.

In particular, social science theorists, in particular sociologists, have proposed their theses in order to explain the new social structure through various correlations, conceptual designs, imaginary narratives, relationship networks and the dynamics that they consider to be basic. This kind of disclosure of the new type of society is an indication of an important wealth in the name of science. Because, the types of societies that were previously based on simple or some binary classifications are now examined with multiple definitions. The positive side of this wealth in the name of science is that there are certain uncertainties produced by these theses for the society. The uncertainty of the new society exceeds the theoretical framework of the theorists.

Every reading style of society redefines the concepts of proximity and distance by their own perspectives. How to set social distances, the form of distance and proximity measures are predicted from the theoretical point of view. In addition to the individuality basis, different types of 
loneliness are emphasized in a significant part of religious and worldly teachings. While the monotheistic religions construct the continuation of the human race through the theme of loneliness, they mention that the prophets are alone. It is accepted that having a reclusive life is a serious data about the level of religiosity. Concepts such as status, alienation, isolation, patience, age, gender, distribution of income, security in modern life are directly and indirectly related to loneliness. It is said that there are positive and negative aspects of loneliness. While loneliness is negative in the sense of abandonment, loneliness in the sense of retreat and being alone with itself is evaluated positively. While in non-modern societies individuality keeps a negative meaning, it refers to a desired process in modern societies. The ways in which societies define and position themselves determine the content of the approach to the concept of loneliness. The manners of reading society are fed by different perspectives and paradigms. Every form of evaluation about society is set to work by keeping it from a certain point. Evaluations around certain problems and phenomena are shown as forms of expressing and explaining society. The limits of understanding and explaining society are determined by the references of the paradigm.

During the emergence of social sciences, the pointer was always turning in favor of the society in the process of evaluating the society and the individual. The majority of the studies on the structure and content of society were focused on the structure. The answer of questions such as what society is, how it should be, the social cohesion and how the conflict takes place tends to be tangential to the individual in general. Mechanical and organic solidarity, historical materialism, and traditional-charismatic-rational types of authority in fact correspond to community typologies. However, the type of the new urban individual brought about by modernization warned about the necessity of reviewing the society. The acceptance of the concept of loneliness brought about by modernization and individualization has increasingly continued. The analyses that are made and will made regarding society focused on the state of loneliness caused by individualization. The individual, who is the negative other of the social structure in the traditional world, played a leading role in the modern era. The general acceptance of interpretations and approaches to society is based on the fact that loneliness is the main determinant. The main sources 
of reference on which conceptions such as risk society, the society of transparency, the network society, the control society are the sources in which loneliness is manifested. Every form of identification of the society essentially informs how loneliness is and should be understood. In this respect, loneliness, according to the definitions of society, gains new meanings each time. Some approaches identify loniless as insecurity and risk; some analyses are expressed in terms of being individual and free, and standing on their feet while explaining society. While loneliness is something to be envied in some places, it sometimes calls for a disgusting image. As a result, the attempt to explain society and the state of society refer to the state of loneliness.

Society types have been conceptualized by almost every social scientist being considered according to various social dynamics. These multiple definitions have important richness in terms of social science yet bring with them some uncertainties. Loneliness is not a phenomenon seen just in the new society types. However, its being that popular is specific to the new society types. Loneliness is a phenomenon frequently mentioned by sociology theorists rather than a psychological approach. The individualiza-tion phenomenon which is one of the basic features of the new society types, is coded as an important factor of loneliness. Loneliness can be said to have many dimensions like spatial, relational, religious, economic, cultural, political, class and etc. In this study, the psychological definitions and debates related to the loneliness phenomenon are put aside and where the states of loneliness coincide in the types of society is discussed through various concepts, social phenomena and institutions, theo-ry/theorists and daily life practices. In the study, the sociological aspects of the loneliness phenomenon in the societies conceptualized by important social science theorists are analyzed. Thus, it focuses on sociologists' approaches to the new society types and their definitions of loneliness. In this context, it is aimed to create kind of a "conceptual loneliness map". 


\section{Kaynakça / References}

Alver, K. (2007). Siteril hayatlar. Ankara: Hece Yayınları.

Arendt, H. (2014). Totaliterizmin kaynakları-III. (çev. İsmail Serin). İstanbul: İletişim Yayınları.

Aydemir, M. A. (2011). Sosyal sermaye. Konya: Çizgi Kitabevi Yayınları.

Baudrillard, J. (2016). Tüketim toplumu. (8. Basım). (çev. Hazal Deliceçaylı ve Ferda Keskin). İstanbul: Ayrıntı Yayınları.

Bauman, Z. (2015). Bireyselleşmiş toplum.(3. Baskı). (çev. Yavuz Alogan). İstanbul: Ayrıntı Yayınları.

Beck, U. (2011). Risk toplumu: Başka bir modernliğe doğru. (çev. Kasım Özdoğan ve Bülent Doğan). İstanbul: İthaki Yayınları.

Becker, H. S. (2016). Toplumu anlatmak.(çev. Şerife Geniş vd.). Ankara: Heretik Yayınları.

Berger, P. L.; Luckmann, T. (2015). Modernite, çoğulculuk ve anlam krizi. (çev. Mustafa Derviş Dereli). Ankara: Heretik Yayınları.

Bogardus, E. S. (1933). A social distance scale. Sociology \& Social Research $17,265-271$.

Bourdieu, P. (2002). The forms of capital. Readings in Economic Sociology, (ed. Nicole W. Biggart). Oxford: Blackwell Publishing, p. 280-291.

Castells, M. (2013). Enformasyon çă̆gi \& Ekonomi, toplum ve kültür: Ă̆g toplumunun yükselişi (Birinci Cilt). (3. Baskı). (çev. Ebru Kılıç). İstanbul: İstanbul Bilgi Üniversitesi Yayınları.

Coleman, J.S. (1988). Social capital in the creation of human capital. The American Journal of Sociology, 94, 95-120.

De J. G.; Jenny, van T.; Theo G. ve Dykstra, P. A. (2006). Loneliness and social isolation, in D. Perlman \& A. Vangelisti (Eds.), The Cambridge Handbook of Personal Relationships (pp. 485-500). Camridge: Cambridge University Press.

De Tocqueville, A. (2016). Amerika'da demokrasi. (çev. Seçkin Sertdemir Özdemir). İstanbul: Ayrıntı Yayınları.

Debord, G. (2012). Gösteri toplumu. (4. Basım) (çev. Ayşen Ekmekçi ve Okşan Taşkent). İstanbul: Ayrıntı Yayınları.

DiTommaso, E.; Spinner, B. (1997). Social and emotional loneliness: A reexamination of Weiss' typology of loneliness. Personality and Individual Differences, 22(3),411-421. 
Dove, P. (2015). Loneliness vs. aloneness: What's the difference?, https://www.huffingtonpost.com/pragito-dove/loneliness-valoneness-wh_b_8032702.html, 24.08.2015, e.t.: 10.01.2019.

Eagleton, T. (2015). Postmodernizmin yanılsamaları. (3. Basım). (çev. Mehmet Küçük). İstanbul: Ayrıntı Yayınları.

Goffman, E. (2017b). Kamusal alanda ilişkiler. (çev. M. Fatih Karakaya). Ankara: Heretik Yayınları.

Goffman, E. (2017a). Etkileşim ritüelleri: Yüz yüze davranış üzerine denemeler. (çev. Adem Bölükbaşı). Ankara: Heretik Yayınları.

Günerigök, M. (2018). Risk toplumu ve din: Yeni bir sosyolojiye doğru. Ankara: Maarif Mektepleri Yayınları.

Haldun, İ. (2013). Mukaddime I,II. (haz. Süleyman Uludağ). İstanbul: Dergâh Yayınları.

Han, B.-C. (2017a). Yorgunluk toplumu. (çev. Samet Yalçın). İstanbul: Açılımkitap Yayınları.

Han, B.-C. (2017b). Şeffaflık toplumu. (çev. Haluk Barışcan). İstanbul: Metis Yayınları.

Heidegger, M. (2012). Niçin taşrada kalıyorum? (1934). Özne,16. Kitap, s. 205-207.

Gazali, İ. (2014). Uzlet (Yalnızlı̆̆ın Faziletleri).(çev. Harun Ünal). İstanbul: Çelik Yayınevi.

Killeen, C. (1998). Loneliness: An epidemic in modern society. Journal of Advenced Nursing, 18(4), 762-770.

Mengüşoğlu, T. (2015). İnsan felsefesi. İstanbul: Doğu Batı Yayınları

Mestroviç, S. G. (1997). Duyguötesi toplum. (çev. Abdullah Yılmaz). İstanbul: Ayrintı Yayınları.

Oskay, Ü. (1994). Kent ve kentlilik üzerine. Varlık Dergisi, 1036, 2-7.

Peplau, L. A.; Perlman, D. (1979). Blueprint for a social psychological theory of loneliness, In M. Cook \& G. Wilson (Eds.), Love and attraction. Oxford, England: Pergamon, 99-108.

Putnam, R. (2000). Bowling alone: American's declining social capital. Journal of Democracy, 6(1), 65-78.

Riesman, D. (2016). Yalnız kalabalık. (çev. Yeşim Erdem). Ankara: Heretik Yayınları.

Ritzer, G. (2016). Büyüsü bozulmuş dünyayı yeniden büyülemek. (4. Basım) (çev. Funda Payzın). İstanbul: Ayrıntı Yayınları. 
Rojek, C. (2003). Şöhret. (çev. Semra Kunt Akbaş ve Kürşad Kızıltuğ). İstanbul: Ayrıntı Yayınları.

Rokach, A. (2014). Leadership and loneliness. International Journal of Leadership and Change, 2(1), 48-58.

Sayer, D.; Frisby, D. (2017). Toplum. (çev. Batuhan Bekmen). İstanbul: Habitus Yayınları.

Sennett, R. (2010). Kamusal insanin çöküşü. (3. Basım) (çev. Serpil Durak \& Abdullah Y1lmaz). İstanbul: Ayrıntı Yayınları.

Sennett, R. (2012). Beraber. (çev. İkbay Özküralpli). İstanbul: Ayrıntı Yayınları.

Simmel, G. (2009). Bireysellik ve kültür.(çev. Tuncay Birkan). İstanbul: Metis Yayınları.

Sombart, W. (1998). Aşk, lüks ve kapitalizm. (çev. Necati Aça) İstanbul: Bilim ve Sanat Yayınları.

Sønderby, L. C. (2013). Loneliness: An integrative approach. Journal of Integrated Social Sciences, 3(1),1-29.

Svendsen, L. (2018). Yalnızlı̆̆ın felsefesi. (2. Baskı). (çev. Mutar Erşen). İstanbul: Redingot Yayınları.

Vattimo, G. (2012). Şeffaf toplum. (çev. Ümit Hüsrev Yolsal). İstanbul: Say Yayınları.

Veblen, T. B. (2017). Aylak sinıfin teorisi: Kurumlarm iktisadi incelemesi. (3. Basım) (çev. Eren Kırmızıaltın ve Hüsnü Bilir). Ankara: Heretik Yayınları.

Weiss, R. (1973). Loneliness: The experience of social and emotional loneliness. USA: MIT Press.

Yaşar, M. R. (2007). Yalnızlık. Fırat Üniversitesi Sosyal Bilimler Dergisi, 17(1), 237-260.

Younger, J. B. (1995). The alienation of the sufferer. Advances in Nursing Sicence 17(4), 53-72.

https://www.euronews.com/2018/01/17/britain-appoints-minister-forloneliness-to-tackle-social-isolation, 17.01.2018, e.t.: 09.01.2019.

https://www.euronews.com/2019/01/01/brits-should-take-their-grandparents-on-family-holidays-minister-says, $\quad 01.01 .2019$, e.t.: 09.01.2019. 


\section{Kaynakça Bilgisi / Citation Information}

Ulutaş, E. ve Gökçen, A. (2019). Toplum tipleri ve yalnızlık halleri. OPUSUluslararası Toplum Araştırmaları Dergisi , 10(17), 1809-1835. DOI: 10.26466/opus.519612 